Trends in Southeast Asia 


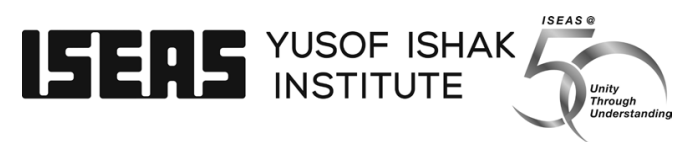

The ISEAS - Yusof Ishak Institute (formerly Institute of Southeast Asian Studies) is an autonomous organization established in 1968. It is a regional centre dedicated to the study of socio-political, security, and economic trends and developments in Southeast Asia and its wider geostrategic and economic environment. The Institute's research programmes are grouped under Regional Economic Studies (RES), Regional Strategic and Political Studies (RSPS), and Regional Social and Cultural Studies (RSCS). The Institute is also home to the ASEAN Studies Centre (ASC), the Nalanda-Sriwijaya Centre (NSC) and the Singapore APEC Study Centre.

ISEAS Publishing, an established academic press, has issued more than 2,000 books and journals. It is the largest scholarly publisher of research about Southeast Asia from within the region. ISEAS Publishing works with many other academic and trade publishers and distributors to disseminate important research and analyses from and about Southeast Asia to the rest of the world. 


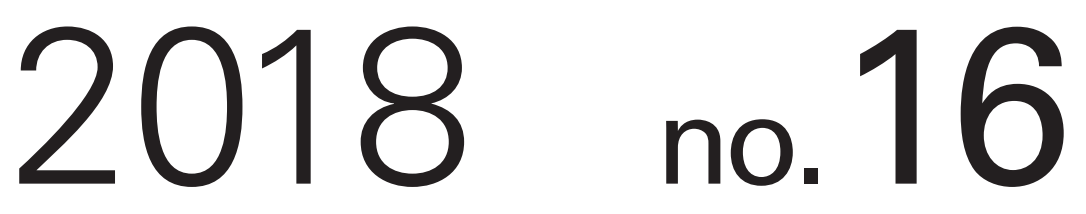

\section{Trends in Southeast Asia}

DEVELOPING EASTERN JOHOR:

THE PENGERANG INTEGRATED

PETROLEUM COMPLEX

SERINA RAHMAN

HEAS YNSOF ISHAK 
Published by: ISEAS Publishing

30 Heng Mui Keng Terrace

Singapore 119614

publish@iseas.edu.sg http://bookshop.iseas.edu.sg

C) 2018 ISEAS - Yusof Ishak Institute, Singapore

All rights reserved. No part of this publication may be reproduced, stored in a retrieval system, or transmitted in any form, or by any means, electronic, mechanical, photocopying, recording or otherwise, without prior permission.

The author is wholly responsible for the views expressed in this book which do not necessarily reflect those of the publisher.

\section{ISEAS Library Cataloguing-in-Publication Data}

Serina Rahman.

Developing Eastern Johor : the Pengerang Integrated Petroleum Complex. (Trends in Southeast Asia Series, 0219-3213 ; TRS16/18)

1. Pengerang Integrated Petroleum Complex.

2. Petroleum industry and trade-Malaysia—Johor.

3. Petroleum refineries-Malaysia-Johor.

4. Petroleum chemicals industry-Malaysia-Johor.

5. Petroleum industry and trade-Social aspects—Malaysia-Johor.

6. Petroleum industry and trade - Environmental aspects-MalaysiaJohor.

I. Title.

II. Series: Trends in Southeast Asia ; TRS16/18.

DS501 I59T no. 16(2018) July 2018

ISBN 978-981-4818-69-8 (soft cover) ISBN 978-981-4818-70-4 (ebook, PDF)

Typeset by Superskill Graphics Pte Ltd Printed in Singapore by Mainland Press Pte Ltd 